\title{
Malocclusion indices and their applications in public health: a review study
}

Índices de oclusopatia e suas aplicações em saúde pública: estudo de revisão

Indicaciones de maloclusión y sus aplicaciones en salud pública: un estudio de revisión

Suzely Adas Saliba MOIMAZ ${ }^{1}$

Cláudia Silva GONÇALVES ${ }^{2}$

Fernando Yamamoto CHIBA ${ }^{3}$

Artênio José Isper GARBIN ${ }^{4}$

Tânia Adas SALIBA ${ }^{4}$

${ }^{1}$ Full Professor, São Paulo State University (UNESP), School of Dentistry, Department of Preventive and Restorative Dentistry, 16015-050 Araçatuba - SP, Brazil

${ }^{2}$ Post graduate student, São Paulo State University (UNESP), School of Dentistry, Department of Preventive and Restorative Dentistry, 16015-050 Araçatuba - SP, Brazil

${ }^{3}$ Assistant Professor, São Paulo State University (UNESP), School of Dentistry, Department of Preventive and Restorative Dentistry, 16015-050 Araçatuba - SP, Brazil

${ }^{4}$ Associate Professor, São Paulo State University (UNESP), School of Dentistry, Department of Preventive and Restorative Dentistry, 16015-050 Araçatuba - SP, Brazil

\section{Abstract}

Health indices are important to measurement of the presence and severity of diseases. The objective of this study was to perform a literature review about malocclusion indices and analyze their applications in the public health field. The research was performed by consulting Pubmed, SciELO, Web of Science, Scopus, Bireme and Embase databases, using the following terms: public health, epidemiological methods, indices, epidemiological surveys, preventive dentistry, malocclusion, and orthodontics. Publications on the development and use of malocclusion indices in clinical and epidemiological studies were included, without restrictions of methodology and language. Fifty-two indices and their variations were identified. Of these, most were intended for individual assessments and their use in public health was difficult due to the requirements for their application, including the need for specialists, plaster models analysis, complementary exams such as cephalometric radiographs and photographs, specific equipment, the need for longitudinal monitoring of cases, and exclusively objective or subjective assessments. Some malocclusion indices present positive aspects and partially evaluate physical, functional, psychological, and social conditions. However, it is still challenging to find a unanimous index that fulfills the requirements for assessing the severity, treatment need, and impact of malocclusions on the individual's quality of life with applicability in public health.

Descriptors: Malocclusion; Public Health; Epidemiologic Methods; Health Surveys.

\section{Resumo}

Os índices de saúde são importantes para mensurar a presença e a severidade das doenças. O objetivo neste estudo foi realizar uma revisão da literatura sobre índices de oclusopatia e analisar suas aplicações na saúde pública. A pesquisa foi realizada por meio de consulta às bases de dados Pubmed, SciELO, Web of Science, Scopus, Bireme e Embase, utilizando os termos: saúde pública, métodos epidemiológicos, índices, levantamentos epidemiológicos, odontologia preventiva, má oclusão e ortodontia. Foram incluídas publicações sobre o desenvolvimento e uso de índices de oclusopatia em estudos clínicos e epidemiológicos, sem restrições de metodologia e idioma. Cinquenta e dois índices e suas variações foram identificados. Destes, a maioria destinava-se a avaliações individuais e sua utilização em saúde pública era limitada pelos requisitos de sua aplicação, como necessidade de especialistas, análise de modelos de gesso, exames complementares como radiografias cefalométricas e fotografias, equipamentos específicos, necessidade de acompanhamento longitudinal, e avaliações exclusivamente objetivas ou subjetivas. Alguns índices de maloclusão apresentam aspectos positivos e avaliam parcialmente as condições físicas, funcionais, psicológicas e sociais, entretanto, ainda é um desafio identificar um índice unânime para avaliação da severidade, necessidade de tratamento e impacto das oclusopatias na qualidade de vida do indivíduo, com aplicabilidade na saúde pública.

Descritores: Má Oclusão; Saúde Pública; Métodos Epidemiológicos; Inquéritos Epidemiológicos.

\section{Resumen}

Los índices de salud son importantes para medir la presencia y gravedad de enfermedades. El objetivo de este estudio fue realizar una revisión de la literatura sobre índices de maloclusión y analizar sus aplicaciones en salud pública. La investigación se llevó a cabo consultando las bases de datos Pubmed, SciELO, Web of Science, Scopus, Bireme y Embase, utilizando los términos: salud pública, métodos epidemiológicos, índices, encuestas epidemiológicas, odontología preventiva, maloclusión y ortodoncia. Se incluyeron publicaciones sobre el desarrollo y uso de índices de maloclusión en estudios clínicos y epidemiológicos, sin restricciones de metodología y lenguaje. Se han identificado cincuenta y dos índices y sus variaciones. De estos, la mayoría estaban destinados a evaluaciones individuales y su uso en salud pública estaba limitado por los requisitos de su aplicación, como la necesidad de especialistas, análisis de modelos de yeso, exámenes complementarios como radiografías y fotografías cefalométricas, equipos específicos, la necesidad de seguimiento longitudinal. , y evaluaciones exclusivamente objetivas o subjetivas. Algunos índices de maloclusión tienen aspectos positivos y evalúan parcialmente las condiciones físicas, funcionales, psicológicas y sociales, sin embargo, aún es un desafío identificar un índice unánime para evaluar la gravedad, necesidad de tratamiento e impacto de las maloclusiones en la calidad de vida del individuo, con aplicabilidad en salud pública.

Descriptores: Maloclusión; Salud Pública; Métodos Epidemiológicos; Encuestas Epidemiológicas.

\section{INTRODUCTION}

Action planning, strategy development, and public health decision-making must be supported by accurate and reliable epidemiological data. Therefore, health indices are of fundamental importance since they allow the measurement of the presence and severity of diseases and provide information for the development and efficient application of public health policies ${ }^{1}$.

Malocclusion is the third major oral health problem, which may affect self-esteem due to aesthetic, speech, functional, and psychosocial changes, impairing the individual's quality of life $e^{2-6}$. Thus, it is necessary to develop appropriate indices for the analysis of malocclusions in population studies, highlighting 
their functionality in determining the need and priority for treatment besides detecting objective signs and providing information that allows a careful social analysis and enables the rational allocation of human, material, and financial resources for orthodontic therapy in public health ${ }^{7}$.

Epidemiological studies show that the prevalence of malocclusions can vary from $62 \%$ to $95.73 \%$ between 6 and 9 years of age, and despite these significant values, malocclusions remain unresolved in most cases $^{8,9}$. The denomination of malocclusions involves dental, facial, and skeletal abnormalities of varying degrees and severity, besides the different effects on the functions of the stomatognathic system and the individual's quality of life, resulting in a complex challenge to develop and standardize applicable malocclusion indices in public health ${ }^{6}$.

Several malocclusion indices have been proposed over time using different evaluation criteria; however, the utility for individual diagnosis and epidemiological studies must be analyzed ${ }^{4}$. Moreover, the lack of standardization of a malocclusion index limits the comparison between studies and causes difficulties in the development of actions aimed at defining the need for treatment in the public health context ${ }^{10}$. Therefore, this study conducted a literature review on malocclusion indices and developed a critical analysis of their applications in public health in the world.

\section{MATERIAL AND METHOD}

This review study included works published in the Pubmed, SciELO, Web of Science, Scopus, Bireme, and Embase databases. The databases search considered the period from 1899 to 2019 and used the following descriptors: public health, epidemiological methods, indices, epidemiological surveys, preventive dentistry, malocclusion, and orthodontics. Publications on the development and use of malocclusion indices in clinical and epidemiological studies were included, without restrictions of methodology and language. The titles and abstracts of the articles found were evaluated, and the eligible versions were obtained for full reading and analysis.

\section{RESULTS AND DISCUSSION}

Through the complete reading of the selected articles, 52 indices and their variations were identified for the evaluation of malocclusions. Table 1 presents the main characteristics of the identified indices.
Table 1. Malocclusion indices according to the author, year of development and description.

\begin{tabular}{|c|c|c|}
\hline Index & Author(s) & Description \\
\hline Angle Classification & Angle $(1899)^{11}$ & $\begin{array}{l}\text { The index classified the malocclusions evaluating the } \\
\text { first maxillary and mandibular permanent molars into } \\
\text { class I, with the first maxillary molar mesiovestibular } \\
\text { cusp occluding at the mandibular first molar } \\
\text { mesiobuccal sulcus; class II, composed of division 1: } \\
\text { buccal central incisors and division 2: lingualized } \\
\text { incisors; class III, with the maxillary first molar } \\
\text { mesiovestibular cusp occluding behind at the } \\
\text { mandibular first molar mesiobuccal sulcus. }\end{array}$ \\
\hline $\begin{array}{l}\text { Lischer } \\
\text { Classification }\end{array}$ & Lischer (1912) $)^{12}$ & $\begin{array}{l}\text { The index classified dental positioning as } \\
\text { neutralocclusion, disto-occlusion, mesio-occlusion, } \\
\text { mesioversion, distoversion, linguoversion, } \\
\text { labioversion, infraversion, supraversion, axioversion, } \\
\text { gyroversion, transversion, besides maxillary } \\
\text { malformations in macrognathia and micrognathia. }\end{array}$ \\
\hline $\begin{array}{l}\text { Stanton Model } \\
\text { Analysis }\end{array}$ & Stanton $(1936)^{13}$ & $\begin{array}{l}\text { The index evaluated the malocclusions in plaster } \\
\text { models using Stanton's pantograph. He transferred } \\
\text { images from the models, in an enhanced manner, to } \\
\text { paper and calculated the dental features. }\end{array}$ \\
\hline $\begin{array}{l}\text { Hellman's } \\
\text { anthropometric } \\
\text { index }\end{array}$ & Hellman (1941) & $\begin{array}{l}\text { The index elaborated on the determination of the } \\
\text { malocclusions utilizing bars that were used directly on } \\
\text { the individual's face, obtaining measurements of the } \\
\text { angles of the face to determine the need for treatment. }\end{array}$ \\
\hline $\begin{array}{l}\text { Moore's Index of } \\
\text { Clinical Needs }\end{array}$ & Moore $(1944)^{15}$ & $\begin{array}{l}\text { The index determined the need for orthodontic } \\
\text { treatment according to the severity of the } \\
\text { malocclusions, using Angle's classification in } \\
\text { association with deleterious habits, such as digital } \\
\text { sucking, nail-biting, lip biting, among others. It } \\
\text { recommended a broad treatment, preventive or } \\
\text { palliative treatment, future treatment, or observation. }\end{array}$ \\
\hline $\begin{array}{l}\text { Prevalence and } \\
\text { Incidence Index }\end{array}$ & $\begin{array}{l}\text { Massel \& Frankel } \\
(1951)^{16}\end{array}$ & $\begin{array}{l}\text { Based on Angle's classification, the index was used in } \\
\text { epidemiological surveys, adding information on tooth } \\
\text { positioning outside the normal range. }\end{array}$ \\
\hline $\begin{array}{l}\text { Cephalometric } \\
\text { Analysis }\end{array}$ & Dows $(1948)^{17}$ & $\begin{array}{l}\text { A quantitative method for evaluating malocclusions } \\
\text { using cephalometric radiographs, and linear and } \\
\text { angular measurements on teeth and skull. }\end{array}$ \\
\hline Facial Ortometer & Elsasser $(1951)^{18}$ & $\begin{array}{l}\text { The index determined the presence of malocclusion } \\
\text { using the facial orthometer, equipment containing } \\
\text { metal stems with predefined markings, and directed to } \\
\text { specific points on the face, to perform measurements } \\
\text { to determine and quantify the malocclusion. }\end{array}$ \\
\hline $\begin{array}{l}\text { Occlusion Feature } \\
\text { Index (OFI) }\end{array}$ & $\begin{array}{l}\text { National Institute of } \\
\text { Dental Research, } \\
\text { Poulton }(1957)^{19}\end{array}$ & $\begin{array}{l}\text { The National Institute of Dental Research classified the } \\
\text { malocclusions as very small, mild, moderate, or severe, } \\
\text { f considering the presence of crowding, intercuspation, } \\
\text { dental projection, and deep or open bite. It correlated } \\
\text { the presence of malocclusions with the development of } \\
\text { periodontal diseases. }\end{array}$ \\
\hline Malalignment Index & $\begin{array}{l}\text { Van Kirk \& Pennel } \\
(1959)^{20}\end{array}$ & $\begin{array}{l}\text { The index used a customized plastic ruler to measure } \\
\text { changes in dental positions, assigning scores to the } \\
\text { measurement results, and assessing the severity of the } \\
\text { malocclusions, thus seeking to conduct epidemiological } \\
\text { surveys and address the need for orthodontic } \\
\text { treatment. }\end{array}$ \\
\hline $\begin{array}{l}\text { Handicapping } \\
\text { Labio-lingual } \\
\text { Deviations (HLD) }\end{array}$ & $\begin{array}{l}\text { Draker \& Albany } \\
(1960)^{2}\end{array}$ & $\begin{array}{l}\text { The index classified the malocclusions according to } \\
\text { their severity into mild, disabling, or disfiguring. The } \\
\text { severity of the malocclusion was evaluated considering } \\
\text { the presence of cleft palate, defects due to trauma, } \\
\text { dental projection, deep or open bite, mandibular } \\
\text { protrusion, an abnormal eruption of teeth, crowding, } \\
\text { and lip-lingual projection. }\end{array}$ \\
\hline $\begin{array}{l}\text { Dentofacial } \\
\text { Anomaly Set }\end{array}$ & WHO $(1962)^{21}$ & $\begin{array}{l}\text { The index defined the Set of Dentofacial Anomalies to } \\
\text { standardize the nomenclature of malocclusions. It } \\
\text { clarified that these were causes of deformity and } \\
\text { needed treatment. }\end{array}$ \\
\hline Bjoerk Index & $\begin{array}{l}\text { Bjoerk et al. } \\
(1964)^{22}\end{array}$ & $\begin{array}{l}\text { The index determined the presence of malocclusions } \\
\text { using a metal instrument appropriate for } \\
\text { measurement, evaluating dental projection, open bite, } \\
\text { laterality, midline, and diastema. It estimated the type, } \\
\text { duration, and time to start treatment. }\end{array}$ \\
\hline $\begin{array}{l}\text { Treatment Priority } \\
\text { Index (TPI) }\end{array}$ & Grainger $(1967)^{23}$ & $\begin{array}{l}\text { The index evaluated the malocclusions and treatment } \\
\text { priority considering the following factors: teeth out of } \\
\text { position, crowded teeth, dental projection, deep bite, } \\
\begin{array}{l}\text { open bite, congenital anomalies, altered } \\
\text { anteroposterior intermaxillary relationship, and } \\
\text { crossbite. }\end{array}\end{array}$ \\
\hline $\begin{array}{l}\text { Eastman Esthetic } \\
\text { Index (EEI) }\end{array}$ & $\begin{array}{l}\text { Howitt et al. } \\
(1967)^{24}\end{array}$ & $\begin{array}{l}\text { The index diagnosed the presence of malocclusions and } \\
\text { treatment priority by applying a questionnaire on } \\
\text { personal satisfaction regarding dental appearance and } \\
\text { assessing occlusal and dental features such as deep } \\
\text { bite, dental projection, open bite, lip-lingual deviation, } \\
\text { gyroversions, the severity of mandibular crowding, } \\
\text { diastemas, and fractures in anterior teeth. }\end{array}$ \\
\hline $\begin{array}{l}\text { Freer \& Adkin } \\
\text { Index }\end{array}$ & $\begin{array}{l}\text { Freer \& Adkin } \\
(1968)^{25}\end{array}$ & $\begin{array}{l}\text { The index evaluated the presence of malocclusions and } \\
\text { treatment priority using plaster models identifying } 40 \\
\text { occlusal and dental characteristics such as dental } \\
\text { projection, deep or open bite, Angle's classification, } \\
\text { midline, etc. The data was processed in computer } \\
\text { programs. }\end{array}$ \\
\hline $\begin{array}{l}\text { Handicapping } \\
\text { Malocclusion } \\
\text { Assessment Record } \\
\text { (HAMAR) }\end{array}$ & Salzmann $(1968)^{26}$ & $\begin{array}{l}\text { The index classified the malocclusions and treatment } \\
\text { priority according to severity. It applied a specific } \\
\text { questionnaire to parents and performed a clinical } \\
\text { examination or used a plaster model to evaluate palatal } \\
\text { clefts, dental spacing, deep or open bite, crossbite, } \\
\text { changes in dental positions, and the sagittal } \\
\text { relationship of first molars. }\end{array}$ \\
\hline \begin{tabular}{l|} 
Oral Health \\
Surveys: Basic \\
methods. 1st edition
\end{tabular} & WHO $(1971)^{27}$ & $\begin{array}{l}\text { The index was published in the first edition of Oral } \\
\text { Health Surveys: Basic methods, providing clear } \\
\text { information on malocclusions, and advising on the } \\
\text { need for orthodontic treatment. }\end{array}$ \\
\hline Occlusal Index (OI) & Summers $(1971)^{28}$ & $\begin{array}{l}\text { The index determined the presence of malocclusions by } \\
\text { evaluating dental development, molar relationship, } \\
\text { dental projection, deep or open bite, crossbite, tooth } \\
\text { displacement, midline changes, and absence of } \\
\text { permanent teeth. It classified them as good, small } \\
\text { deviations without treatment need, small deviations } \\
\text { with small treatment needs, and larger deviations with } \\
\text { more complex treatment needs. }\end{array}$ \\
\hline
\end{tabular}


Table 1 (Continuation). Malocclusion indices according to the author, year of development and description.

\begin{tabular}{|c|c|c|}
\hline Index & Author(s) & Description \\
\hline $\begin{array}{l}\text { The Six Normal } \\
\text { Occlusion Keys }\end{array}$ & Andrews (1972) ${ }^{29}$ & $\begin{array}{l}\text { The index determined the presence of malocclusions } \\
\text { through molar relationships, tooth angulations, tooth } \\
\text { inclinations, tooth rotations, tooth contacts, and the } \\
\text { Spee curve. }\end{array}$ \\
\hline Baume Index & Baume et al. 1973) ${ }^{30}$ & $\begin{array}{l}\text { The index was composed of } 3 \text { categories: dental } \\
\text { measurement (agenesis, supernumerary teeth, } \\
\text { malformed teeth, teeth included, transposed teeth), } \\
\text { intra-arch (crowding, spacing, anterior irregularities, } \\
\text { diastema), and inter-arch (molar relationship, } \\
\text { posterior open bite, posterior crossbite, dental } \\
\text { projection, deep or open bite, midline deviation, } \\
\text { affected soft tissue). }\end{array}$ \\
\hline $\begin{array}{l}\text { Uniform Method } \\
\text { for Measuring } \\
\text { Occlusal Traits }\end{array}$ & $\begin{array}{l}\text { WHO }(1973)^{31} ; \text { FDI } \\
(1973)^{32}\end{array}$ & $\begin{array}{l}\text { The index aimed to develop a system to measure } \\
\text { malocclusions with broad applications and results that } \\
\text { could be compared. It examined the permanent } \\
\text { dentition through dental, intra-arch, and inter-arch } \\
\text { examinations. }\end{array}$ \\
\hline $\begin{array}{l}\text { Index Swedish } \\
\text { Medical Health } \\
\text { Board (ISMHB) }\end{array}$ & $\begin{array}{l}\text { Linder-Aronson } \\
(1974)^{33}\end{array}$ & $\begin{array}{l}\text { The index determined the need for orthodontic } \\
\text { treatment with priority for disabling cases. Composed } \\
\text { of } 4 \text { grids: Grid } 4 \text { treatment required disabling features } \\
\text { (cleft lip or palate, retained upper incisors and } \\
\text { extensive aplasia), Grids } 3 \text { and } 2 \text { involved elective } \\
\text { treatment (deep bite with gingival irritation, crossbite } \\
\text { transverse, canines retained, dental rotations with } \\
\text { aesthetic and/or functional impairment, incisor } \\
\text { inclinations with aesthetic and/or functional } \\
\text { impairment, deep bite, crowding or spacing, infra- } \\
\text { occlusion and moderate rotations), and Grid } 1 \text { involved } \\
\text { no change. }\end{array}$ \\
\hline $\begin{array}{l}\text { Ingervall \& } \\
\text { Ronnerman Index }\end{array}$ & $\begin{array}{l}\text { Ingervall \& } \\
\text { Ronnerman } \\
(1975)^{34}\end{array}$ & $\begin{array}{l}\text { The index determined the presence of malocclusions } \\
\text { and treatment priority based on abnormal dental } \\
\text { positions, occlusal abnormalities, space anomalies, } \\
\text { disorders involving the masticatory system, and } \\
\text { disorders of the occlusal system. }\end{array}$ \\
\hline $\begin{array}{l}\text { Little's Irreg } \\
\text { Index }\end{array}$ & Little $(1975)^{35}$ & $\begin{array}{l}\text { The index evaluated the need for treatment according } \\
\text { to the severity of the malocclusions using a pachymeter } \\
\text { in a plaster model, measured dental crowding, and } \\
\text { classified them as perfect, mild, moderate, severe, or } \\
\text { very severe alignments. }\end{array}$ \\
\hline Gottlieb Index & Gottlieb $(1975)^{36}$ & $\begin{array}{l}\text { The index evaluated the outcome of orthodontic } \\
\text { treatment observing characteristics such as molar } \\
\text { relationship, canine relationship, intercuspation, open } \\
\text { or deep bite, dental projection, midline, rotations, } \\
\text { crowding or spacing, arch shape, torques, and dental } \\
\text { parallelism. }\end{array}$ \\
\hline $\begin{array}{l}\text { Kowalski \& Prahal- } \\
\text { Andersen Index }\end{array}$ & $\begin{array}{l}\text { Kowalshi \& Prahal- } \\
\text { Andersen }(1976)^{37}\end{array}$ & $\begin{array}{l}\text { The index determined treatment priority based on } \\
\text { clinical criteria such as dental projection, deep or open } \\
\text { bite, upper intermolar distance, joint-gonion-mento } \\
\text { angle, lower arch length, and angle resulting from the } \\
\text { difference in maxillary and mandibular size. }\end{array}$ \\
\hline $\begin{array}{l}\text { Oral Health } \\
\text { Surveys: Basic } \\
\text { methods. 2nd } \\
\text { edition }\end{array}$ & WHO (1977) $)^{38}$ & $\begin{array}{l}\text { The index recognized that there was no consensus for a } \\
\text { malocclusion index, and recommended that it should } \\
\text { be developed by understanding community health, } \\
\text { economic, and social factors. }\end{array}$ \\
\hline Eismann Index & Eismann (1980)39 & $\begin{array}{l}\text { The index evaluated the effectiveness of orthodontic } \\
\text { treatment by observing before, in the end, and after the } \\
\text { installation of the retainer. It observed factors that } \\
\text { could generate occlusion recurrences such as crowding, } \\
\text { spacing, anterior open bite, posterior open bite, } \\
\text { crossbite, dental projection, deep bite, midline, } \\
\text { transverse changes, incisor rotations, axial } \\
\text { inclinations, buccal canine eruption, and } \\
\text { anteroposterior relationship. }\end{array}$ \\
\hline $\begin{array}{l}\text { Berg \& Freudlund } \\
\text { Classification }\end{array}$ & $\begin{array}{l}\text { Berg \& Freudlund } \\
(1981)^{40}\end{array}$ & $\begin{array}{l}\text { The index determined the solubility of orthodontic } \\
\text { treatment based on dental projection, anterior } \\
\text { crossbite, deep bite, anterior and lateral open bite, uni } \\
\text { or bilateral crossbite, and top-to-top bite, which were } \\
\text { attributed scores before and after treatment. }\end{array}$ \\
\hline $\begin{array}{l}\text { Dental Facial } \\
\text { Attractiveness } \\
\text { (DFA) }\end{array}$ & $\begin{array}{l}\text { Tedesco et al. } \\
(1983)^{41}\end{array}$ & $\begin{array}{l}\text { The index used extraoral photographs with a } \\
\text { classification ranging from "very attractive" to "least } \\
\text { attractive" so that they could be judged by dentists and } \\
\text { individuals in need of orthodontic treatment. } \\
\text { Developed with the purpose of determining facial } \\
\text { attractiveness as a reference for the need for } \\
\text { orthodontic treatment. }\end{array}$ \\
\hline $\begin{array}{l}\text { thetic } \\
\text { I) }\end{array}$ & Cons et al. (1986)42 & $\begin{array}{l}\text { The index diagnosed the presence of malocclusions, the } \\
\text { severity and need for orthodontic treatment by } \\
\text { examining dental absences, crowding in the incisor } \\
\text { region. spacing in the incisor region, diastemas, } \\
\text { anterior maxillary misalignment, anterior mandibular } \\
\text { misalignment, anterior maxillary projection, anterior } \\
\text { mandibular projection, anterior open bite, and molar } \\
\text { relationship. The changes were assigned different } \\
\text { weights resulting in a score that determined the } \\
\text { severity and, consequently, the need for treatment. }\end{array}$ \\
\hline $\begin{array}{l}\text { Oral Health } \\
\text { Surveys: Basic } \\
\text { methods. 3th } \\
\text { edition }\end{array}$ & WHO $(1987)^{3}$ & $\begin{array}{l}\text { It was recommended the Malocclusion Index to } \\
\text { diagnose malocclusion in } 5 \text {-year-old children according } \\
\text { to conditions: o-normal, no occlusal changes; } 1 \text {-light, } \\
\text { with the presence of gyroversions or mild crowding } \\
\text { and/or spacing with loss of regular alignment; 2- } \\
\text { moderate/severe, unacceptable defect in facial } \\
\text { appearance, or impaired chewing function, phonetic } \\
\text { problems due to maxillary projection of } 9 \mathrm{~mm} \text { or more, } \\
\text { anterior crossbite greater than or equal to one tooth, } \\
\text { open bite, midline altered by } 4 \mathrm{~mm} \text { or more, crowding } \\
\text { or spacing of } 4 \mathrm{~mm} \text { or more; and 9-no information, no } \\
\text { possibility of evaluation, or when age is inappropriate. }\end{array}$ \\
\hline $\begin{array}{l}\text { Richmond } \\
\text { Classification }\end{array}$ & Richmond (1987) ${ }^{43}$ & $\begin{array}{l}\text { The index evaluated the intensity and oriented the } \\
\text { treatment plan of the malocclusions using plaster } \\
\text { models to evaluate the dental projection, open or deep } \\
\text { bite, midline, mesial-distal diameter, inter-canine } \\
\text { angles, inter-incisive angles, occlusal planes, inter- } \\
\text { canine distance, inter-molar distance, parabolic curve, } \\
\text { and discrepancies. }\end{array}$ \\
\hline $\begin{array}{l}\text { Standardized } \\
\text { Continuum of } \\
\text { Aesthetic Need } \\
\text { (SCAN) }\end{array}$ & $\begin{array}{l}\text { Evans \& Shaw } \\
(1987)^{44}\end{array}$ & $\begin{array}{l}\text { The index determined orthodontic treatment priority } \\
\text { using a dental attractiveness scale comprising 10 } \\
\text { extraoral photographs with various dental positions. } \\
\text { The images were evaluated by dental surgeons, } \\
\text { parents, and youths affected by malocclusions. }\end{array}$ \\
\hline
\end{tabular}

Table 1 (Continuation). Malocclusion indices according to the author, year of development and description.

\begin{tabular}{|c|c|c|}
\hline Index & Author(s) & Description \\
\hline $\begin{array}{l}\text { Index of } \\
\text { Orthodontic } \\
\text { Treatment Need } \\
\text { (IOTN) }\end{array}$ & \begin{tabular}{|l} 
Brook \& Shaw \\
$(1989)^{45}$
\end{tabular} & $\begin{array}{l}\text { The index diagnosed the presence of malocclusions and } \\
\text { the need for treatment using the Dental Health } \\
\text { Component (DHC) and the Aesthetic Component (AC). } \\
\text { The DHC was determined using a customized plastic } \\
\text { ruler for dental measurement while the CA evaluated } \\
\text { dental attractiveness based on the SCAN index } 44 \text {. }\end{array}$ \\
\hline $\begin{array}{l}\text { Peer Assessment } \\
\text { Rating (PAR) }\end{array}$ & $\begin{array}{l}\text { Richmond et al. } \\
(1992)^{46,47}\end{array}$ & $\begin{array}{l}\text { The index evaluated the results of orthodontic } \\
\text { treatment on plaster models before and after } \\
\text { orthodontic therapy with the aid of a customized ruler. } \\
\text { The index offered uniformity and standardization in } \\
\text { the evaluation of orthodontic treatment results. }\end{array}$ \\
\hline $\begin{array}{l}\text { Necessity } \\
\text { Orthodontic } \\
\text { Treatment Index } \\
\text { (NOTI) }\end{array}$ & $\begin{array}{l}\text { Espeland et al. } \\
(1992)^{48}\end{array}$ & $\begin{array}{l}\text { The index measured the need for orthodontic } \\
\text { treatment using questionnaire, morphological and } \\
\text { functional analyses present in clinical exams, occlusal } \\
\text { analysis of orthodontic models, and radiographs. It } \\
\text { classified the malocclusions into } 4 \text { groups: } 1 \text { )very great } \\
\text { need; 2)great need; 3)obvious need; 4) no need. }\end{array}$ \\
\hline $\begin{array}{l}\text { Ingelsson- } \\
\text { Dahlstrom \& } \\
\text { Hagberg Index }\end{array}$ & $\begin{array}{l}\text { Ingelsson- } \\
\text { Dahlstrom \& } \\
\text { Hagberg (1994) }\end{array}$ & $\begin{array}{l}\text { The index determined the need for treatment in } \\
\text { children by evaluating dental projection, deep or open } \\
\text { bite, and first molar relationship. Used the } 4 \text { grades of } \\
\text { ISMHB and suggested that early treatment avoided } \\
\text { worsening of malocclusions over time. }\end{array}$ \\
\hline Peerlings Index & Peerlings $(1995)^{50}$ & $\begin{array}{l}\text { The index developed a scale for quantifying dentofacial } \\
\text { aesthetics using standardized extraoral photographs } \\
\text { before and after orthodontic treatment. It suggested } \\
\text { that dentofacial aesthetics was the most important } \\
\text { factor concerning orthodontic treatment. }\end{array}$ \\
\hline $\begin{array}{l}\text { Malocclusion Index } \\
\text { - Supplement }\end{array}$ & $\begin{array}{l}\text { Brazilian Ministry } \\
\text { of Health (2001) })^{51}\end{array}$ & $\begin{array}{l}\text { The index suggested changes in the Malocclusion } \\
\text { Index, adding to category } 1 \text { (mild), information of } \\
\text { dental changes, such as uni or bilateral posterior } \\
\text { crossbite, deep bite, or dental projection above } 2 \mathrm{~mm} \text {. }\end{array}$ \\
\hline $\begin{array}{l}\text { Oral I } \\
\text { Surve }\end{array}$ & WHO (1997) ${ }^{52}$ & $\begin{array}{l}\text { It was assessed malocclusions more comprehensively, } \\
\text { including criteria for dental assessment and analysis of } \\
\text { permanent occlusion with DAI validation }{ }^{42} \text {. }\end{array}$ \\
\hline $\begin{array}{l}\text { Objective Grading } \\
\text { System \& } \\
\text { Comprehensive } \\
\text { Clinical Assessment } \\
\text { (OGS \& CCA) }\end{array}$ & $\begin{array}{l}\text { American Board } \\
\text { Orthodontics. } \\
\text { Casko (1998) } \\
\text { Pinskaya et al. } \\
(2004)^{54}\end{array}$ & $\begin{array}{l}\text { The index determined treatment results using the } \\
\text { occlusal and radiographic exams before and after } \\
\text { orthodontic treatment, with the following dental } \\
\text { features: alignment, marginal ridges, vestibule-lingual } \\
\text { inclinations, occlusal contacts, projection, inter- } \\
\text { proximal contacts, and root angulation. The CCA } \\
\text { evaluated factors such as facial shape, dental } \\
\text { aesthetics, vertical dimension, gums, and roots, before } \\
\text { and after orthodontic treatment. }\end{array}$ \\
\hline Kirschen Index & Kirschen (1998)55 & $\begin{array}{l}\text { The index determined the presence of malocclusions, } \\
\text { at } 9 \text { and } 14 \text { years of age, by non-specialist professionals } \\
\text { and with rapid implementation. It evaluated late } \\
\text { eruption, crowding, pronounced dental projection of } 4 \\
\text { mm or more, crossbite, infraocclusion of deciduous } \\
\text { molars, palate palpation of canines, presence of } \\
\text { cavities, deep bite, and open bite. }\end{array}$ \\
\hline $\begin{array}{l}\text { Risk of } \\
\text { Malocclusion Index } \\
\text { (ROMA) }\end{array}$ & $\begin{array}{l}\text { Russo et al. } \\
(1998)^{56}\end{array}$ & $\begin{array}{l}\text { The index used a personalized form with } 5 \text { grids: } \\
\text { systemic problems, craniofacial problems, dental } \\
\text { problems, functional problems, and no listed problems. } \\
\text { The test result classified the malocclusions in } 5 \text { grades: } \\
\text { minimum risk, mild, moderate, large, and extreme. } \\
\text { Determined the severity and the need for treatment. }\end{array}$ \\
\hline \begin{tabular}{l|} 
Handicapping \\
Labio-lingual \\
Deviations- \\
California \\
Modification (HLD \\
- CalMod) \\
\end{tabular} & Parker (1999) ${ }^{57}$ & $\begin{array}{l}\text { The index determined the need for orthodontic } \\
\text { treatment by assigning scores to the clinical } \\
\text { examination of the individual with malocclusions, } \\
\text { evaluating characteristics such as dental projection } \\
\text { above } 9 \mathrm{~mm} \text {, anterior crossbite, deep accentuated bite } \\
\text { with tissue destruction, cleft palate, etc. This was a } \\
\text { variation of the HDL index }{ }^{2} \text {. }\end{array}$ \\
\hline $\begin{array}{l}\text { Index of Complexity } \\
\text { Outcome and Need } \\
\text { (ICON) }\end{array}$ & $\begin{array}{l}\text { yaniel \& Richmond } \\
(2000)^{58}\end{array}$ & $\begin{array}{l}\text { The index evaluated the characteristics in plaster or } \\
\text { clinical models using IOTN-AC, crossbite, } \\
\text { alignment/spacing in the upper arch, buccal } \\
\text { relationship in the anteroposterior segment, and } \\
\text { vertical relationships in the anterior segment. }\end{array}$ \\
\hline \begin{tabular}{l|} 
Handicapping \\
Labio-lingual \\
Deviations- \\
Maryland \\
modification (HLD \\
- Md)
\end{tabular} & $\begin{array}{l}\text { Hans \& Davison } \\
(2001)^{59}\end{array}$ & $\begin{array}{l}\text { The index used Angle's classification and the HLD } \\
\text { variables } 2,11 \text {. The HLD Md considered class II severe, } \\
\text { deep tissue destructive bites, anterior tissue destructive } \\
\text { crossbites, and unilateral posterior crossbites. Reduced } \\
\text { HLD's need for treatment scores to } 2 \mathrm{~mm} \text { for dental } \\
\text { projection and } 3 \mathrm{~mm} \text { for a deep or open bite. }\end{array}$ \\
\hline Facial Patterns & Capelozza $(2004)^{60}$ & $\begin{array}{l}\text { The index classified the malocclusions by facial } \\
\text { morphology. The patterns were determined in frontal } \\
\text { and lateral visual outlets: Pattern I has facial } \\
\text { normality, without sagittal or vertical changes; } \\
\text { Patterns II and III with deficiency or excess } \\
\text { mandibular development, respectively, with } \\
\text { abnormalities that could be detected with the } \\
\text { individual in the lateral position; long or short face } \\
\text { pattern includes vertical skeletal discrepancies that } \\
\text { could be assessed with the individual in the frontal } \\
\text { position. }\end{array}$ \\
\hline $\begin{array}{l}\text { Treatment } \\
\text { Difficulty Index } \\
\text { (TDI) }\end{array}$ & Pitt et al. $(2006)^{61}$ & $\begin{array}{l}\text { The index detected the difficulty of planning and } \\
\text { performing the orthodontic treatment in cases } \\
\text { including canines. It employed methodologies similar } \\
\text { to the PAR index, using plaster models and } \\
\text { radiographs before and after orthodontic } \\
\text { treatment } 46 \text { 6.47. It evaluated treatment time, rectangular } \\
\text { arch use, and traction. }\end{array}$ \\
\hline $\begin{array}{l}\text { Oral Health } \\
\text { Surveys: Basic } \\
\text { methods. 5th } \\
\text { edition }\end{array}$ & WHO (2013) ${ }^{62}$ & $\begin{array}{l}\text { It indicated that the guidelines of previous manuals } \\
\text { should be followed, without mentioning the use of new } \\
\text { malocclusion indices. It suggested that epidemiological } \\
\text { surveys should be conducted every five or six years in } \\
\text { the same community to prevent and measure the } \\
\text { impact and effectiveness of disease control, with results } \\
\text { directed at public health policies. }\end{array}$ \\
\hline $\begin{array}{l}\text { Baby Risk of } \\
\text { Malocclusion Index } \\
\text { (Baby ROMA) }\end{array}$ & $\begin{array}{l}\text { Grippaudo et al. } \\
(2014)^{63}\end{array}$ & $\begin{array}{l}\text { The index identified malocclusions in } 5 \text {-year-old } \\
\text { children. Determined early treatment or follow-up, and } \\
\text { identified risks for installation or worsening of the } \\
\text { problem as high, medium, or low. Based on the ROMA } \\
\text { index, it formulated four grades: systemic, craniofacial, } \\
\text { dental, and functional } 5 \text {. Regarding scores from } 1 \text { to } 5 \text {, } \\
\text { scores } 1 \text { and } 2 \text { required observation, score } 3 \text { indicated } \\
\text { possible worsening of the problem requiring follow-up } \\
\text { before the growth spurt, and scores } 4 \text { and } 5 \text { indicated } \\
\text { the need for immediate treatment. }\end{array}$ \\
\hline
\end{tabular}


Several indices have been developed over the years to evaluate malocclusions considering different aspects in their development, including identification, classification, and severity, need, applicability, and priority of treatment, functional changes, psychosocial disorders, and evaluation of orthodontic treatment efficiency and solubility. Most of the indices were appropriate for individual evaluations; however, their use in public health was difficult due to certain applicability conditions, including the need for specialists, plaster models, complementary exams such as cephalometric radiographs, photographs, specific equipment, and the need for longitudinal monitoring besides requiring exclusive objective or subjective evaluations. Thus, in the context of public health, the importance of assessing the need and priority for the treatment of individuals is highlighted, as well as obtaining information to adequately allocate the necessary resources to meet the population demand and avoid social inequities $^{64,65}$.

Angle's classification was one of the first indices elaborated in 1899 by Angle, the "father of modern orthodontics", who elected Apollo de Belvedere's face as normal ${ }^{11}$. However, this classification determined the presence of sagittal malocclusions, omitting data related to transverse and vertical discrepancies ${ }^{11,66}$. With the recession of 1929 and the advent of the First and Second World Wars, public health issues increased due to the global situation of social collapse. This contributed to the search for indices that could determine the need for orthodontic treatment in public health because, until then, the specialty was considered accessible only to wealthy individuals ${ }^{67,68}$.

It should be noted that malocclusion indices can be used from an individual perspective comprising objective factors or a public health perspective considering population groups, defining malocclusions as a dental and skeletal change that can cause a social disadvantage ${ }^{4}$. In this sense, for decades the World Health Organization (WHO) has been making recommendations for the problem to reach the public spheres coherently ${ }^{3,27,38,52,62}$. In 1962, the WHO proposed the structuring of standardized methods for the study of oral diseases, naming malocclusions as a "Set of Dentofacial Anomalies" ${ }^{21}$.In 1971, the first edition of the Oral Health Surveys: Basic methods was published, providing guidance on the need for orthodontic treatment ${ }^{27}$. Aiming at broad application and reproducibility, the WHO and the World Dental Federation developed the
Uniform Method for Measuring Occlusal Traits; however, this method did not evaluate psychosocial factors in individuals affected by malocclusions ${ }^{31,32,69}$.

The second edition of Oral Health Surveys: Basic methods described a lack of consensus on an index for malocclusions and suggested that the measurement of these dysfunctions should consider health, economic, and social factors ${ }^{38}$. In its third edition, the Oral Health Surveys: Basic methods presented the Malocclusion Index to diagnose and measure malocclusions in 5-year-old children ${ }^{3,9,70}$. The Oral Health Surveys: Basic method in its fourth edition suggested the Dental Aesthetic Index (DAl) to be considered as the standard for the epidemiological survey of malocclusions ${ }^{52}$. In the 5th edition, the Oral Health Surveys: Basic methods did not recommend a new index for malocclusions and suggested following the general guidelines of the previous editions ${ }^{62}$.

Such efforts reflect the difficulty and need to institute an adequate and standardized index for the evaluation of malocclusions in epidemiological studies. Several indices such as the Stanton Model Analysis, Hellman's Anthropometric Index, and Moore's Clinical Needs Index were useful in evaluating individual malocclusions, but the need for specific equipment, complementary tests, and specialists made it difficult to apply them in studies with larger samples ${ }^{13-15}$. Similarly, Dows developed an evaluation method based on cephalometric radiographs, with adequate results for individual diagnosis ${ }^{17}$; however, it was expensive, time consuming, and complex for use in epidemiological surveys. Elsasser clinically evaluated malocclusions using a facial orthometer and although it could be used by non-specialists, this method presented a functional gap because it did not define treatment priorities ${ }^{18}$.

An important issue related to the development of malocclusion indices is the restricted approach of objective clinical information, such as dental and occlusal characteristics, disregarding the psychosocial aspect which may restrict its application in public health, as observed in the Index of Prevalence and Incidence, Occlusion Feature Index (OFI), Six Keys of Normal Occlusion, Kowalski and Prahl-Andersen Index, Richmond Index, and Kirschen Index ${ }^{16,19,29,37,43,55}$.

To relate the severity of malocclusions with the need for treatment, several indices such as Handicapping Labio-lingual Deviations (HLD), Occlusal Index (OI), Malalignment Index, Treatment Priority Index (TPI), Index Swedish 
Medical Health Board (ISMHB), Little Irregularity Index, and Handicapped Labio-Lingual Deviation index with California modifications (HLD CalMod), were developed based on exclusively clinical and objective criteria for indicating and clarifying the need for orthodontic intervention ${ }^{2,20,23,28,33,35,57}$. However, they presented gaps in public health applications because they did not consider the individual's social context.

Facial morphology was used as a basis for evaluating malocclusions, as proposed in the Ingervall and Ronnerman index and the Facial Pattern analysis; considering the physiognomy to determine the presence of the pathology, with little applicability in epidemiological surveys. ${ }^{34,60}$ Other indices exclusively analyzed the presence and need for treatment of malocclusions, thereby limiting their use in public health, such as the Standardized Continuum of Aesthetic Need (SCAN), and the Peerlings index, which were based on evaluations of extraoral photographs, highlighting the relationship of treatment with the search for improved aesthetics and self-esteem ${ }^{44,50}$.

Some indices considered the importance of both objective and subjective characteristics. The Eastman Esthetic Index (EEI) analyzed dental characteristics and applied a questionnaire on personal satisfaction ${ }^{24}$. The Freer and Adkins index ensured that the individual was not excluded from treatment based only on clinical criteria ${ }^{25}$. The Handicapping Malocclusion Assessment Record (HAMAR), Baume index, and the Dental Facial Attractiveness (DFA) considered the effects caused by malocclusions on the quality of life ${ }^{26,30,41}$; however, their application was timeconsuming.

Similarly, the Index of Orthodontic Treatment Need (IOTN) was developed by linking the Dental Health Component, which assessed the type of malocclusion and treatment priority, to the Aesthetic Component, which assessed facial attractiveness, containing subjective and objective characteristics with potential utility in the social realm ${ }^{45}$. The DAI considered the impact of dental characteristics in the individual's psychosocial context and classified the severity of the malocclusions and the need for treatment ${ }^{42}$. The index attributed different weights to each type of occlusal and dental alteration, considering the psychosocial impacts involved, and was recommended in the fourth edition of Oral Health Surveys: Basic methods ${ }^{52}$. The Necessity Orthodontic Treatment Index (NOTI) determined the need for orthodontic treatment through the application of questionnaires and clinical evaluation ${ }^{48}$; however, besides physical, sociocultural, and emotional information, the index used radiographs to complement the decision on the need for treatment, thereby limiting its applicability in epidemiological studies. The Risk of Malocclusion Index (ROMA) evaluated dental, physical, and functional characteristics, classified the malocclusions, and diagnosed the severity and need for orthodontic treatment ${ }^{56}$. It can be performed by several health professionals and consists of a grid with results involving the psychosocial factors. Considering the importance of preventive actions, the Baby ROMA index, a variant of the ROMA index, classified the malocclusions and identified the risks involved in installation or aggravation of the problem, implying the need for early follow-up or intervention ${ }^{56,63}$. The need and solubility of orthodontic treatment were evaluated using the Index of Complexity Outcome and Need (ICON), based on international parameters ${ }^{58}$. Similarly, the Gottlieb index, Eismann index, Berg and Freudlund classification, Peer Assessment Rating index (PAR), and the Objective Grading System (OGS) \& Comprehensive Clinical Assessment (CCA) index compared dental characteristics before and after orthodontic treatment and measured the effectiveness of orthodontic therapy ${ }^{36,39,40,46,47,53,54}$.

The evolution of malocclusion indices shows that dental and skeletal changes caused by the pathology are often eclipsed by the psychological and social impact, which is considered extremely valuable in determining the need and priority for treatment. Therefore, indices that include clinical parameters but do not encompass the individual's social and psychological context limit their application in the public health scenario.

CONCLUSION

Several malocclusion indices have been proposed over a century and although some of them present positive aspects and evaluate physical, functional, psychological, and social conditions, it is still a challenge to unanimously adopt an index that includes the requirements for assessing the severity, need for treatment, and impact of malocclusions on the individual's quality of life with global applicability to public health policies.

ACKNOWLEDGEMENTS

This study was financed in part by the Coordenação de Aperfeiçoamento de Pessoal de Nível Superior - Brasil (CAPES) - Finance Code 001. 


\section{REFERENCES}

1. Orton L, Lloyd-Williams F, Taylor-Robinson D, O'Flaherty M, Capewell S. The use of research evidence in public health decision making processes: systematic review. PLoS One. 2011;6(7):e21704.

2. Draker HL. Handicapping labio-lingual deviations: a proposed index for public health purposes. Am J Orthod. 1960;46:295-305.

3. World Health Organization. Oral health surveys: basic methods. 3rd ed. Geneva: WHO; 1987.

4. Chaves MM. Social Dentistry. 3rd ed. São Paulo: Artes Médicas;1986.

5. Ghafari M, Bahadivand-Chegini S, Nadi T, Doosti-Irani A. The global prevalence of dental healthcare needs and unmet dental needs among adolescents: a systematic review and meta-analysis. Epidemiol Health. 2019;41: e2019046.

6. Snowden CB, Miller TR, Jensen AF, Lawrence BA. Costs of medically treated craniofacial conditions. Public Health Rep. 2003;118:10-17.

7. Prahl-Andersen B. The need for orthodontic treatment. Angle Orthod. 1978;48:1-9.

8. Garbin AJI, Perin PCP, Garbin CAS, Lolli LF. Malocclusion prevalence and comparison between the Angle classification and the Dental Aesthetic Index in scholars in the interior of São Paulo state - Brazil. Dental Press J Orthod. 2010;15:94-102.

9. Brazilian Ministry of Health. SBBrazil 2010 Project: National Oral Health Survey - Main Results. Brasília: Brazilian Ministry of Health; 2011 [Accessed 2020 Oct 13]. Available from: http://bvsms.saude.gov.br/bvs/publicacoes/SBB rasil_2010.pdf.

10.Gray AS, Demirjian A. Indexing occlusions for dental public health programs. Am J Orthod. 1977;72(2):191-97.

11. Angle EH. Classification of malocclusion. Dent Cosmos. 1899;41:248-64.

12. Lischer BE. Principles and methods of orthodontia. Philadelphia,PA: Lea \& Febiger; 1912.

13. Stanton FL. A quantitative study of dental occlusion between 2 and 10 years. Dent Cosmos. 1936;78:130-40.

14. Hellman M. Diagnosis in orthodontic practice. Am J Orthod Oral Surg. 1941;27:681-704.

15. Moore GR. An introduction to the formulation of a method of occlusal examination for public health survey purposes. Ann Arbo: University of Michigan; 1944.

16. Massler M, Frankel JM. Prevalence of malocclusion in children aged 14 to 18 years. Am J Orthod. 1951;37:751-68.

17. Downs WB. Variations in facial relationships: their significance in treatment and prognosis. Am J Orthod. 1948;34:812-40.
18.Elsasser WA. Studies of dento-facial morphology. I. A simple instrument for appraising variations. Angle Orthod. $1951 ; 21: 163-71$.

19. Poulton DR, Aaronson SA. The relationship between occlusion and periodontal status. Am J Orthod. 1961;47:690-9.

20. Van Kirk LE, Pennell EH. Assessment of malocclusion in population groups. Am J Public Health Nations Health. 1959;49:1157-63.

21. World Health Organization. Standardization of reporting of dental diseases and conditions: report of an expert committee on dental health; 1962 [Accessed 2020 Oct 13]. Available from: https://apps.who.int/iris/handle/10665/38150

22. Bjoerk A, Krebs AA, Solow B. A method for epidemiological registration of malocculusion. Acta Odontol Scand. 1964;22:27-41.

23. Grainger RM. Orthodontic treatment priority index. Vital Health Stat 2. 1967;25:1-49.

24. Howitt JW, Stricker G, Henderson R. Eastman esthetic index. N Y State Dent J. 1967;33: 215-20.

25. Freer TJ, Adkins BL. New approach to malocclusion and indices. J Dent Res. 1968;47:1111-17.

26. Salzmann JA. Handicapping malocclusion assessment to establish treatment priority. Am J Orthod. 1968;54:749-65.

27. World Health Organization. Oral health surveys: basic methods. Geneva: WHO; 1971.

28. Summers CJ. The occlusal index: a system for identifying and scoring occlusal disorders. Am J Orthod. 1971;59:552-67.

29. Andrews LF. The six keys to normal occlusion. Am J Orthod. 1972;62:296-309.

30. Baume LJ, Horowitz HS, Summers CJ, Dirks OB, Brown WA, Carlos JP, et al. A method for the measurement of occlusal characteristics. (Developed for the commission on classification and statistics of the FDI, (COCSTOC) study group 2 on dentofacial abnormalities, 1969-72). Int Dent J. 1974;24:90-7.

31. World Health Organization. International classification of diseases, application to dentistry and stomatology (ICD - DA). Geneva: WHO; 1973.

32. Federation Dentaire Internationale (FDI). A method of measuring occlusal traits. Developed by the FDI commission on classification and statistics for oral conditions, working group 2 on dento-facial anomalies. Int Dent J. 1973; 23:530-37.

33. Linder-Aronson S. Orthodontics in the Swedish public dental health service. Trans Eur Orthod Soc. 1974;233-40.

34. Ingervall $B$, Rönnerman A. Index for need of orthodontic treatment. Odontol Revy. 1975;26:59-82. 
35. Little RM. The irregularity index: a quantitative score of mandibular anterior alignment. Am J Orthod. 1975;68:554-63.

36. Gottlieb EL. Grading your orthodontic treatment results. J Clin Orthod. 1975;9:155-61.

37. Kowalski CJ, Prahl-Andersen B. Selection of dentofacial measurements for an orthodontic treatment priority index. Angle Orthod. 1976;46:94-7.

38. World Health Organization. Oral health surveys: basic methods. 2nd ed. Geneva: WHO; 1977.

39. Eismann D. Reliable assessment of morphological changes resulting from orthodontic treatment. Eur J Orthod. 1980;2: 19-25.

40.Berg R, Fredlund A. Evaluation of orthodontic treatment results. Eur J Orthod. 1981;3:181-85.

41. Tedesco LA, Albino JE, Cunat JJ, Green LJ, Lewis EA, Slakter MJ. A dental-facial attractiveness scale. Part I. Reliability and validity. Am J Orthod. 1983;83:38-43.

42. Cons NC, Jenny J, Kohout K. DAl: the dental aesthetic index. lowa City: College of Dentistry, University of lowa; 1986.

43. Richmond S. Recording the dental cast in three dimensions. Am J Orthod Dentofacial Orthop. 1987;92:199-206.

44. Evans R, Shaw W. Preliminary evaluation of an illustrated scale for rating dental attractiveness. Eur J Orthod. 1987;9:314-8.

45. Brook PH, Shaw WC. The development of an index of orthodontic treatment priority. Eur $\mathrm{J}$ Orthod. 1989;11:309-20.

46. Richmond S, Shaw WC, O'Brien KD, Buchanan IB, Jones $R$, Stephens $C D$, et al. The development of the PAR index (Peer assessment rating): reliability and validity. Eur $\mathrm{J}$ Orthod. 1992;14:125-39.

47. Richmond S, Shaw WC, Roberts CT, Andrews $M$. The PAR index (Peer assessment rating): methods to determine outcome of orthodontic treatment in terms of improvement and standards. Eur J Orthod. 1992;14:180-87.

48. Espeland LV, Ivarsson K, Stenvik A. A new Norwegian index of orthodontic treatment need related to orthodontic concern among 11-yearolds and their parents. Community Dent Oral Epidemiol. 1992;20:274-79.

49. Ingelsson-Dahlström M, Hagberg C. The longitudinal development of malocclusion in postnormal children with little respectively urgent need for orthodontic treatment. Swed Dent J. 1994;18:49-57.

50. Peerlings $\mathrm{RH}$, Kuijpers-Jagtman AM, Hoeksma JB. A photographic scale to measure facial aesthetics. Eur J Orthod. 1995;17:101-9.

51. Brazilian Ministry of Health. SB2000 Project: oral health conditions of the Brazilian population in 2000: examiner's manual. Brasília: Brazilian Ministry of Health; 2001 [Accessed 2020 Oct
13].

Available

from:

http://bvsms.saude.gov.br/bvs/publicacoes/con dSB_man_exam.pdf (2001)

52. World Health Organization. Oral health surveys: basic methods. 4th ed. Geneva: WHO; 1997.

53. Casko JS, Vaden JL, Kokich VG, Damone J, James RD, Cangialosi TJ, et al. Objective grading system for dental casts and panoramic radiographs. Am J Orthod Dentofacial Orthop. 1998;114:589-99.

54. Pinskaya YB, Hsieh TJ, Roberts WE, Hartsfield JK. Comprehensive clinical evaluation as an outcome assessment for a graduate orthodontics program. Am J Orthod Dentofacial Orthop. 2004;126:533-43.

55. Kirschen R. Orthodontic clinical screening in under a minute. Br Dent J. 1998;185:224-26.

56. Russo E, Grippaudo C, Marchionni P, Deli R. II ROMA index come metronomo della terapia ortodontica nel paziente in crescita. Procedings national congress of SIDO, Firenze 1998;28-31.

57. Parker WS. A study of 1000 malocclusions selected by the HLD (CalMod) index. Am J Orthod Dentofacial Orthop. 1999;115:343-51.

58. Daniels C, Richmond S. The development of the index of complexity, outcome and need (ICON). J Orthod. 2000;27:149-62.

59. Han H, Davidson WM. A useful insight into 2 occlusal indices: HLD(Md) and HLD(CalMod). Am J Orthod Dentofacial Orthop. 2001;120: 247-53.

60. Capelozza Filho L. Diagnosis in orthodontics. Maringá: Dental Press; 2004.

61. Pitt S, Hamdan A, Rock P. A treatment difficulty index for unerupted maxillary canines. Eur $\mathrm{J}$ Orthod. 2006;28:141-44.

62. World Heath Organization. Oral health surveys: basic methods. 5th ed. Geneva: WHO; 2013.

63. Grippaudo C, Paolantonio EG, Pantanali F, Antonini G, Deli R. Early orthodontic treatment: a new index to assess the risk of malocclusion in primary dentition. Eur $\mathrm{J}$ Paediatr Dent. 2014;15:401-6.

64. Frazão P, Narvai PC, Latorre MRDO, Castellanos RA. Prevalência de oclusopatia na dentição decídua e permanente de crianças na cidade de São Paulo, Brasil, 1996. Cad Saúde Pública. 2002;18:1197-205.

65.Peres KG, Frazão P, Roncalli AG. Padrão epidemiológico das oclusopatias muito graves em adolescentes brasileiros. Rev Saúde Pública. 2013;47:109-17.

66. Pinto EDM, Gondim PPDC, Lima NSD. Análise crítica dos diversos métodos de avaliação e registro das más oclusões. Rev Dent Press Ortod Ortop Facial. 2008;13:82-91.

67. Moore GR. The orthodontic program of the Michigan state department of health with a new classification of occlusion for survey purposes. Am J Orthod. 1948;34:355-61. 
68. Moore GR. Measuring and meeting orthodontic needs of a community. J Am Dent Assoc. 1952;45:650-60.

69. Baume LJ, Maréchaux SC. Uniform methods for the epidemiologic assessment of malocclusion. Am J Orthod. 1974;66:121-9.

70. Oliveira AGRC, Unfer B, Costa ICC, Arcieri RM, Guimarães LOC, Saliba NA. Levantamentos epidemiológicos em saúde bucal: análise da metodologia proposta pela Organização Mundial da Saúde. Rev Bras Epidemiol. 1998;1:177-89.

\section{CONFLICTS OF INTERESTS}

The authors declare no conflicts of interests.

\section{CORRESPONDING AUTHOR}

\section{Fernando Yamamoto Chiba}

Assistant Professor,

São Paulo State University (UNESP),

School of Dentistry,

Department of Preventive and Restorative Dentistry, 16015-050 Araçatuba - SP, Brazil

E-mail: fernando.chiba@unesp.br 